sity of Bristol has provided, in recent years, for the study of experimental zoology. The appointment of a man of Prof. Harris's wide interests and experience may be regarded not only as a source of satisfaction to the University of Bristol, but also as a good augury for the post-war development of zoology in Great Britain.

\section{Chinese Professors Visiting Britain}

Frve Chinese professors have just arrived in Britain, and will be guests of certain colleges at Oxford and Cambridge and of the British Council. They will continue their studies with the view of making British achievements in these fields better known in China. The visitors are : Prof. Chang Tsu-Kung, of the Central China University, an authority on the history of science, who is going to Christ's College, Cambridge ; Prof. Yin Hung-Chang, of the Associated South-Western Universities (Tsing Hua), Kumming, who will do research in plant biochemistry, and will reside at St. John's College, Cambridge; Prof. Chang Hui-Wen, of the Central University of China, where he taught public administration and political science, who is to study public administration in Britain in connexion with the development of the Civil Service examination system in China, and will be attached to Corpus Christi College, Cambridge; Prof. Fan Tsen-Chung, head of the Foreign Languages Department, National Central University, Shapingpa, who will undertake research in English literature (with special reference to English knowledge of China), and will reside in Balliol College, Oxford; Prof. R. C. Fang, head of the Foreign Languages Department, Wuhan University, Kiating, who will undertake research in English literature, and will reside in Trinity College, Cambridge.

\section{French Scientific Mission in Great Britain}

THE executive committee of the Society for Visiting Scientists received the members of the French Scientific Mission on September 16 at the Society's house at 5 Old Burlington Street, London, W.1. Prof. F. G. Donnan expressed a warm welcome to the Mission, which is led by M. L. Rapkine, and includes Prof. J. Hadamard, Prof. Pierre Auger, Prof. Francis Perrin and Dr. R. Wurmser. He said that French civilization and science are an essential part of those of Europe, and, as Voltaire might have said, if they did not exist, it would be necessary to invent them. He hoped that Anglo-French scientific relations will grow at a great pace and become one of the foundations of development in the post-war period. Sir Henry Dale supported Prof. Donnan, and looked forward with particular pleasure to the prospect in the near future of Prof. Hadamard being offially admitted as a foreign member of the Royal Society.

\section{Research in Cotton Growing}

AT a meeting of the Administrative Council of the Empire Cotton Growing Corporation on June 6 several new appointments were made. Mr. Arthur Foster was elected chairman of the Council in succession to the late Sir Richard Jackson and Mr. James Littlewood vice-chairman. The post of director of the Corporation was filled by Mr. L. G. Killby, and Mr. J. C. May was elected secretary. Mr. Killby has also been appointed chairman of the Scientific Committee. The activities of this body have largely been concerned with the arrangements for establishing the new Central Cotton Research Station in Uganda. Though actual building operations cannot begin until after the War, a satisfactory site has been selected, and it is hoped that some preliminary work on it will soon be started. Mr. Parnell and Mr. Hutchinson have been designated for the posts of director and deputy director of the new Station respectively.

The Corporation's report for 1942-43, together with the programmes of work for 1943-44 of each of its seventeen experiment stations, has been submitted in the same form as in previous war years, and can be obtained, price $3 s$., from 37 Inner Park Road, Wimbledon Common, London, S.W.19. The research station in Trinidad is being closed in order that work may be concentrated in the larger cottongrowing countries with the new Station at Uganda as a central feature. This attention to development in research was commended by the President of the Board of Trade in his message to the Corporation at its annual general meeting for, as he said, efforts to improve the quality of cotton grown in the Empire and to increase its yield per acre is a valuable contribution to the prosperity of the Empire as a whole.

\section{Town and Country Planning}

IN view of the important part which engineers are playing and must play in all future planning, the Council of the Institution of Civil Engineers has appointed an Institution Committee to be known as "The Town and Country Planning Committee" to advise the Council on matters relating to the engineer's part in town and country planning. This takes the place of a sub-committee of the Public Relations Committee, which had been dealing with this matter previously. The new Committee will include members who are city engineers and borough surveyors and others who have specialized on roads, railways, docks, water supply, drainage including sewage disposal, and electricity and gas services.

In order to enable engineers and others to keep in touch with present-day principles and ideas in planning, the Council has also arranged a series of four lectures on "The Position of the Engineer in Relation to Town and Regional Planning" on Thursdays at 5 p.m., beginning on October 26. Particulars of the lectures are as follows: October 26, "The Basis of Town and Country Planning", by Mr. H. J. B. Manzoni, city engineer and surveyor, Birmingham; November 2, "Tralfic Problems", by Mr. W. S. Cameron, city engineer and surveyor, Leeds ; November 9, "Drainage, including River Works", by Mr. D. G. Bevan, deputy city engineer and surveyor, Birmingham; November 16, "Services (Electricity, Water, Gas and Post Office)", by Mr. J. Paton Watson, eity engineer and surveyor, Plymouth. These lectures will be open to non-members of the Institution on payment of $2 s .6 d$. for each lecture. Applications for tickets, accompanied by remittances, should be made to the Secretary of the Institution.

\section{Rickettsia Diseases}

The March issue of the Boletin de la Oficina Sanitaria Panamericana contains reports concerming Rocky Mountain spotted fever and the typhus group from five members of the Panamerican Sanitary Bureau Committee on Typhus, namely, Dr. Otávio de Magalhães of Brazil, Dr. L. Pãtino-Camago of Colombia, Dr. A. Recco of Cuba, Dr. C. G. Hidalgo of Ecuador and Dr. G. Varela of Mexico. There 
were, in all, 791 cases of Rocky Mountain spotted fever and 9,625 cases of the typhus group. Brazil reported 663 cases of spotted fever ' in the fourteen years 1929-42, occurring in thirty-six localities of three States (Rio de Janeiro, Minas Gerais and São Paulo), but the report was admittedly incomplete and consisted only of the severe forms of the disease. In Columbia there were 128 cases of Rocky Mountain spotted' fever during 1934-43 in seven localities in two departments. With regard to typhus fever (type not specified), except for Cuba where all the cases were of the murine type, Brazil reported four cases in 1941, Colombia 882 cases in 1942 and the first quarter of 1943 with a case fatality of 10-17.4 per cent in hospital cases. In Mexico there were 8,198 cases of typhus during 1938-42, with 750 in Mexico City, and a case mortality of 14 per cent. In Ecuador there were 517 cases of Rocky Mountain fever and 18 of typhus.

\section{Fulgence Raymond (1844-1910)}

Prof. Fulgence Raymond, a leading Paris neurologist, was born on September 29, 1844, at St. Christophe, Indre et Loire. He first studied veterinary medicine at the School at Alfort, where in 1867 he became director of the department of anatomy and physiology. Afterwards he took up medicine in the Paris faculty under Vulpian and Charcot and qualified in 1876. In 1894 he succeeded Charcot in his hospital practice and in the chair of nervous diseases at La Salpêtrière.

Raymond was well known in Great Britain, where he was made an honorary D.Sc. at Oxford and delivered a lecture at the Royal College of Physicians on "Premature Physiological Senescence localized to certain Organic Systems". He died on September 28, 1910. His chief publications were "Anatomie pathologique du systême nerveux" (1'886), "Maladies du système nerveux" (1889-94) and in collaboration with Janet "Leçons sur les maladies du système nerveux", "Neuroses et idées fixes" (1898), "Obsessions et la psychasthenic" (1903), "Etudes de pathologie nerveuse" (1910). He also made numerous contributions to the Revue Neurologique and L'Encéphale.

\section{Appointments in the University of London}

Dr. C. A. MACE, University reader in psychology at Bedford College, has been appointed as from October 1 to the University chair of psychology tenable at Birkbeck College.

Prof. W. H. MeCrea, since 1936 professor of mathematics at Queen's University, Belfast, and since 1943 temporary principal experimental officer in the Admiralty, has been appointed as from October 1 to the University chair of mathematics tenable at Royal Holloway College.

Prof. Frank Goldby, since 1937 Elder professor of anatomy in the University of Adelaide, has accepted the appointment to the University chair of anatomy tenable at St. Mary's Hospital Medical School, and hopes to take up his post during the session 1945.

\section{Tapeworms in Seagulls and Cormorants}

REFERRING to the report by J. B. Duguid and E. M. Sheppard of the infection of trout in a South Wales reservoir with plerocercoids of a tapeworm belonging to the Diphyllobothriidæ (see Nature of August 5, p. 185), M. D. Hickey and J. R. Harris
(British Med. J., 310, Sept. 2, 1944) report the finding of an adult tapeworm belonging to the genus Diphyllobothrium in seagulls and cormorants in the Dublin area. They think that these birds are the naturally infected definitive hosts of the parasite in this district. Trout from reservoirs near Dublin are heavily infected with plerocercoids belonging to the Diphyllobothriidæ. In the intestines of the greater and lesser black-backed gulls (Larus marinus and L. fuscus), of herring gulls (Larus argentatus) and of cormorants (Phalacrocorax carbo) the authors found all stages of the tapeworm from the plerocercoid found in the fish to the adult tapeworm. Investigation is proceeding and further details will be published later.

\section{The Night Sky in October}

FULL moon occurs on Oct. 2d. 04h. 22m. U.T., and new moon on Oct. $17 \mathrm{~d}$. $05 \mathrm{~h}$. $35 \mathrm{~m}$. The following conjunctions with the moon take place: Oct. 8d. 16h., Saturn $0.3^{\circ}$ N. ; Oct. 14d. 01h., Jupiter $3^{\circ} \mathrm{S}$. ; Oct. $19 \mathrm{~d}$. $20 \mathrm{~h}$., Venus $5^{\circ} \mathrm{S}$. The following occultations of stars brighter than magnitude 6 take place: Oct. 4d. 0h. $18 \cdot 4 \mathrm{~m}$., $\xi^{2} \operatorname{Ceti}(D)$; Oct. 4d. 0h. $47 \cdot 9 \mathrm{~m}$., ${ }^{2}$ Ceti $(R)$; Oct. 6d. 1h. $57 \cdot 0 \mathrm{~m}$., 64 Tauri $(R)$. The times refer to the latitude of Greenwich and $D$ and $R$ refer to disappearance and reappearance respectively. Mercury rises at $4 \mathrm{~h} .38 \mathrm{~m}$. at the beginning of the month and is in superior conjunction on Oct. 20. At the end of the month the planet sets very shortly after the sun. Venus sets at $18 \mathrm{~h} .22 \mathrm{~m}$. and $17 \mathrm{~h} .46 \mathrm{~m}$. at the beginning and end of the month respectively. Mars is too close to the sun for favourable observation. Jupiter, in the constellation of Leo, rises at $3 \mathrm{~h} .48 \mathrm{~m}$., $3 \mathrm{~h} .8 \mathrm{~m}$., and $2 \mathrm{~h} .22 \mathrm{~m}$., at the beginning, middle and end of the month respectively. Saturn, in the constellation of Gemini, sets at $14 \mathrm{~h} .09 \mathrm{~m} ., 13 \mathrm{~h} .16 \mathrm{~m}$., and $12 \mathrm{~h} .13 \mathrm{~m}$. at the beginning, middle and end of the month respectively. The Orionid meteors should be seen during October 18-26.

\section{Announcements}

The Committee of Privy Council for Medical Research has appointed Dr. Alan N. Drury (director of the Lister Institute of Preventive Medicine) and Prof. James C. Spence (professor of child health in the University of Durham and honorary physician to the Royal Victoria Infirmary, Newcastle-uponTyne) to be members of the Medical Research Council as from October 1 .

The Royal Aeronautical Society is arranging a discussion on civil aviation to be held on November 4 at the Institution of Mechanical Engineers. The discussion, which will begin at 10.30 a.m. and continue throughout the day, will be divided into sections dealing with economics, aircraft and aero engine design, route facilities (meteorology, radio, aerodromes, etc.) and the selection and training of personnel. The chair will be taken by Lord Brabazon. Tickets of admission will be available only through members of the Royal Aeronautical Society.

Erratum. In the communication "Standardization of Root Excretions ..." by Dr. C. Ellenby in Nature of September 16, p. 363, for "a second sample is taken" read "the second oxygen determination is made". 